\title{
Pia Vuorio
}

\section{"Din frihet är nära kopplad till min egen" En feministisk psykoanalytisk läsning av emancipations- och modersmotiv i Maud Reuterswärds Elisabet-trilogi}

\begin{abstract}
One of the most complex forms of relationship in fiction for young adults seems to be the one between mothers and daughters. The Swedish author Maud Reuterswärd (1920-1980) has written several books for young adults in which a relational crisis between a mother and her daughter is the central theme. Throughout Reuterswärd's trilogy about Elisabet Hof, the mother plays a key role. The trilogy features an emotionally instable and mentally absent mother whose depression eventually leads to her attempting to commit suicide. Through a psychoanalytical lens, this paper highlights and discusses how the mother-daughter relationship in Reuterswärd's trilo$g y$ is mediated through dialogue, point of view and tone. The mother's voice and the verbal communication between mother and daughter is focused by using Luce Irigaray's theoretical approach of the maternal function in psychoanalysis and culture. In addition the paper attempts to widen the critical perspectives and provide alternative ways of understanding the mother in Reuterswärd's trilogy.
\end{abstract}

Keywords: Maud Reuterswärd, mothers, daughters, Luce Irigaray, voice, family

Maud Reuterswärd, en av sin tids mest uppskattade författare av barn- och ungdomslitteratur, har i tidigare analyser framhävts som en driven skildrare av komplexa och dysfunktionella mödrar. I synnerhet den självdestruktiva mor som Reuterswärd porträtterar i 1970-talets ungdomstrilogi om Elisabet Hof pekas ut som ett typexempel på den emotionellt instabila mor som frekvent figurerar i 1970-talets samtidsrealistiska ungdomsromaner (Svensson; Edström; Westin).

(C2016 Pia Vuorio. This is an Open Access article distributed under the terms of the Creative Commons Attribution-Noncommercial 3.0 Unported License (http://creativecommons.org/ licenses/by-nc/3.0/), permitting all non-commercial use, distribution, and reproduction in any medium, provided the original work is properly cited.

Citation: Barnboken - tidskrift för barnlitteraturforskning/Journal of Children's Literature Research, Vol. 39, 2016 http://dx.doi.org/10.14811/clr.v39i0.254 
Samtidigt skildrar trilogin en liten flickas uppväxt och mognad till ung kvinna, en individuationsprocess utmärkande för ungdomsromaner. Vad som i tidigare analyser lämnats obeaktat är att frigörelsen inte enbart gäller protagonisten utan i hög grad även modern. Det är en smärtsam men likväl en emancipatorisk process för dem båda.

I och med att det inte gjorts någon djupgående vetenskaplig analys av Reuterswärds trilogi hänvisas här till artiklar av mer översiktlig karaktär skrivna av Vivi Edström och Boel Westin. Enligt Edström är modern, som i många andra ungdomsböcker från denna tid, den problematiska figuren hos Reuterswärd. Modern framstår nämligen som en negativ modell för den unga dottern som söker sin identitet och sin väg till frihet (Edström 201).

Westin går ett steg längre i sin tolkning och hänvisar till Irené Matthis psykoanalytiska förklaringsmodell:

\begin{abstract}
Att avskilja sig från modern blir, skriver Matthis i sin bok, "ett mord med ett mordoffer: mordotter." Mellan mor/dotter finns inget "och", och det som i mor och son skiljer det ena från det andra. Dotterns uppgörelse med modern blir därmed desto häftigare och leder i de mest extrema fallen till i stort sett fullfjädrade modermord. I Maud Reuterswärds Ta steget, Elisabet (1973) gör modern ett förtvivlat självmordsförsök. (38)
\end{abstract}

Både Edström och Westin fäster stor uppmärksamhet vid självmordsförsöket och Westin ser dottern Elisabet som en katalysator för moderns desperata tilltag. Vad både Edström och Westin lämnar osagt är att dottern spelar en avgörande roll för mammans konvalescens. Efter självmordsförsöket sjunker mamman ner i ett långvarigt ordlöst tillstånd och det är dottern som till sist lyckas bryta tystnaden.

Värt att notera är att Kerstin Thorvall, som målar pessimistiska modersporträtt i såväl vuxen- som ungdomsromaner, låter mamman i "Vart ska du gå?" "Vet inte" (1975) fullfölja sitt självmord. Bakgrunden är en smärtsam skilsmässa som i det här fallet inte leder till frigörelse utan till depression och slutligen självförvållad död. Till skillnad från Reuterswärds trilogi är protagonisten en 18-årig pojke som kritiserar sin mamma för att vara en misslyckad hemmafru utan eget liv. När han får höra att mamman begått självmord reagerar han med ilska och tolkar självmordet som en hämndaktion mot barnen och ex-mannen: "För att tvinga dom att bry sig om henne" (145). Mellan mor och son finns inget samförstånd och inget hopp 
om försoning. I sin studie Behovet av närhet blir med åren betydligt större än nödvändigheten att bevara sin värdighet. Om genus, trots och åldrande $i$ Kerstin Thorvalls författarskap (2015) borrar Maria Jönsson djupt i mor-son-relationen i Thorvalls pojkskildringar från 1960-och 1970-talen. Jönsson undersöker bland annat pojkars subjektsblivande genom det relationella samspelet med modern.

\section{Samhällsdebatt om modern}

Reuterswärds trilogi som består av Du har ju pappa, Elisabet (1971), Ta steget, Elisabet (1973) och Livet rymmer allt, Elisabet (1975), är på många vis influerad av dåtidens kritiska debatter om könsroller och kärnfamiljen. Dessa initierades i Sverige redan 1961 då författaren och feministen Eva Moberg publicerade essän "Kvinnans villkorliga frigivning" vars ståndpunkter kom att bli riktgivande för 1970-talets kvinnorörelse (Larsson 255). I essän hävdade Moberg att: "Moderskärleken är historiens mest exploaterade känsla, inte endast i de enskilda fallen utan också i det stora sociala perspektivet" och vidare, att "Både män och kvinnor har en huvudroll, den som människor" (72).

På Mobergs essä följde en långvarig och intensiv debatt om kvinnors och mäns ställning i familjen och i samhället överlag som även påverkade barn- och ungdomslitteraturen. Ying Toijer-Nilsson visar i sin studie hur diskussionen om könsroller i barnböcker hela tiden fördes jämsides och i växelverkan med den allmänna könsrollsdebatten och att de utvecklingsfaser som kvinnorörelsen genomgick även avspeglades i barnlitteraturen (7-21).

Bland annat nämner hon den amerikanska feministen Betty Friedans bok The Feminine Mystique (1963) som en inspirationskälla för de svenska ungdomsförfattarna. En av Friedans teser var att endast ett yrkesarbete kunde ge en kvinna en egen identitet (Friedan 263). Reuterswärds modersporträtt i Elisabet-trilogin ljuder som ett eko av denna tes, men som den här artikeln påvisar betalar modern ett högt pris för sin utbildning och yrkesidentitet.

I den här artikeln argumenterar jag för att det modersporträtt som Reuterswärd målar upp inte är fullt så entydigt som antytts utan att det snarare kan tolkas som ett ställningstagande till dåtidens samhällsdiskussioner. Vidare lyfter jag fram aspekter som enligt min mening förbisetts i tidigare analyser. Dessa granskar jag med stöd av teorier ur feministisk psykoanalys. Genom att ta fasta på de olika berättartekniska greppen som inkluderar dialoger och tonläge mellan karaktärer samt berättarperspektiv i trilogin om Elisabet Hof, vill jag fördjupa bilden av i synnerhet mamman. 
Dialogerna och berättarperspektivet är avgörande i tolkningen av mamman eftersom det finns textavsnitt där den allvetande berättaren enbart fokuserar mammans inre känsloliv. Det här är avsnitt som forskare hittills inte fäst någon större vikt vid. Innan jag går in på själva teorin och textanalysen kan en kort resumé av moderskapet och de centrala karaktärerna i trilogin vara på sin plats.

Becka Hof är gift med skulptören Anders Hof och tillsammans har de dottern Elisabet, som i den första delen Du har ju pappa, Elisabet, är sex år gammal. Becka arbetar dagtid och studerar på kvällarna till lärare medan Anders sköter om Elisabet hemma. Becka beskrivs som en emotionellt frånvarande förälder som har svårt för att visa sina känslor. Dottern har en betydligt närmare relation till sin pappa, en öppenhjärtig, glad och aningen bohemisk man som verkar trivas med sin roll som hemmapappa.

I trilogins andra del Ta steget, Elisabet är protagonisten 16 år. Vemodet som präglade Becka i Du har ju pappa, Elisabet, har nu övergått i en djup depression och kulminerar slutligen i ett självmordsförsök. När Becka vaknar upp från medvetslösheten sjunker hon i stället ner i ett ordlöst tillstånd där hon inte verkar känna igen sin familj längre. Det är Elisabet som lyckas bryta sig igenom mammans tystnad.

I trilogins avslutande del flyttar Elisabet hemifrån. Mellan Becka och Anders finns fortsatta spänningar. Elisabets självständiga liv i studentbostaden tar en dramatisk vändning och hon återvänder till sin hemstad där pappan bjuder på en överraskande bekännelse om att han i sin ungdom haft ett intensivt förhållande med en annan man.

\section{Litterära mödrar och psykoanalys}

Inom feminismen har relationer mellan mödrar och döttrar genererat ett alldeles särskilt intresse: "The most complex form of relationship in feminist literature, however, seems to be the mother/daughter relationship, for that is the primary relationship for many girls", skriver Roberta Seelinger Trites (100). Hon hänvisar till den amerikanska feministen och poeten Adrienne Rich som i sitt banbrytande verk $O f$ Woman Born. Motherhood as Experience and Institution (1976) hävdar att relationen mellan mödrar och döttrar är en social konstruktion skapad av ett patriarkalt system: "Mor-dotter-relationen har, liksom intensiva relationer kvinnor emellan över huvud taget, betraktats som ytterst hotande mot män" (201). I sin bok efterlyste Rich därför feministiska berättelser där denna negligerade relation skulle få sin upprättelse.

Hilary Crew som genomgående analyserat relationen mellan mödrar och döttrar i anglosaxiska sagor och ungdomsromaner 
skriver: "Since Rich's work, feminists have been giving voice to the significance of the mother-daughter relationship" (2). Men där relationer mellan mödrar och redan vuxna döttrar fått den upprättelse som Rich efterlyste i litteratur för vuxna saknas ett liknande mönster i ungdomsromanerna. "If anything, the relationship between teen girls and their mothers has been perceived as even more conflictridden and nonsignificant than the relationship between adult mothers and daughters that has been the focus of attention in feminist studies" (2), menar Crew.

Denna typ av problemfyllda relation är en etablerad komponent även i den svenska ungdomsromanen. Westin konstaterar att bokmödrar fortsatt att vara problemmödrar och räknar upp åtskilliga exempel på "djupt deprimerade, frånvarande, likgiltiga, narcissistiska och monstruöst elaka mödrar" i 1970-, 80- och 90-talets litteratur (37). Begreppet problemmödrar lanserades av Toijer-Nilsson som i sin studie konstaterar att den tid då bokmodern hade auktoritet var förbi redan i början av 1960-talet. Där pappor i patriarkal anda fortsatte att symbolisera lugn och trygghet beskrevs mammor tvärtom som misslyckade (Toijer-Nilsson 202-203).

Feministisk psykoanalys har visat sig vara en användbar teoretisk ingång för att analysera litterära relationer mellan mödrar och döttrar, i synnerhet med tanke på den komplexitet som denna relation verkar vara omgiven av. Det feministiska perspektivet i dessa teorier har gett den traditionella psykoanalysen, formad av Sigmund Freud och Jaques Lacan, en ny, kvinno- och modersbejakande dimension.

Feministisk litteraturteori med psykoanalytisk grund utarbetad av franska teoretiker som Luce Irigaray baserar sig på begreppet le féminine, vars innebörd är betydligt mer mångfacetterad än det adjektiv som i vardagligt bruk beskriver det kvinnliga. För Irigaray är språket, och uttryckligen existensen av det feminina språket, en viktig faktor. Barnlitteraturforskaren Christine Wilkie-Stibbs tillämpar Irigarays teori då hon analyserar språk och skrift i ungdomsromaner där relationen mellan mor och dotter är central (2).

Enligt Wilkie-Stibbs möjliggör utforskandet av det feminina alternativa läsningar av ungdomsromaner, läsningar som synliggör tystnader och frånvaro. I sin analys "Öronbedövande tystnad. Flickskildringen i Peter Pohls Anette-böcker" (2008) tar exempelvis Mia Franck avstamp i berättarperspektivet för att visa hur flickprotagonistens tystnad hos Pohl konstruerar det såväl begränsande som utvidgande aktörskap som flickan förhåller sig till (149). Till detta kan man tillägga att 1970-talets svenska ungdomsroman lämpar sig särskilt väl för utforskandet av det feminina dels på grund av de influenser som könsrollsdebatten gett och dels på grund av den en- 
sidiga tolkning som genrens pessimistiska modersporträtt genererat i tidigare analyser.

Eftersom en feministisk läsning av Elisabet-trilogin kan bringa fram en ny tolkning fokuserar jag i min analys moderns röst och den språkliga kommunikationen mellan mor och dotter. Därav blir Luce Irigarays teori om den icke-erkända modern, ett brukbart analysredskap (Irigaray, "Etablir un généalogy").

Framhävandet av moderns roll och dennas relation till dottern samt återställandet av en språklig obalans, är drivkraften för Irigaray. Vad hon menar är att det feminina språket kan balansera upp den bristande jämvikten mellan manligt och kvinnligt som finns i den lacanska tolkningen av språket. Enligt Irigaray definieras modern i traditionell psykoanalys som en han och kan därför endast tala med en maskulin röst. Modern saknar således en egen röst och ett eget sätt att kommunicera med sina barn.

I Elisabet-trilogins andra del Ta steget, Elisabet, förlorar modern sin talförmåga helt, som en följd av självmordsförsöket. När hon börjar tala igen är det delvis tack vare Elisabet. Kommunikationen mellan mor och dotter går in i en helt ny fas som i enlighet med Irigarays teori kan tolkas som ett feminint språk. Detta resonemang utvecklas senare i textanalysen.

Irigaray kritiserar även det sätt på vilket modersrollen påverkat kvinnans identitet och därför förhindrat henne från att definiera sitt jag, sitt själv. Som mor i relation till sitt barn är hon begränsad till två roller; den "goda modern", vars uppgift är att älska barnet villkorslöst och förse det med föda, eller den "onda modern", som varken älskar eller tillgodoser barnets aptit. Oavsett vilken roll modern tar kan hon utplåna sitt barn med kvävande kärlek respektive ett överflöd av näring eller med en avsaknad av bägge (Grosz 121).

Ur traditionell psykoanalytisk vinkel kan Becka Hof så som hon inledningsvis presenteras tolkas som den "onda" modern. Hon är fåordig, känslomässigt kall och så fokuserad på sina lärarstudier att hon, som en tillfällig lösning, skickar i väg Elisabet och Anders till familjens sommarställe för att kunna slutföra studierna. Med psykoanalytisk terminologi ger hon varken kärlek eller näring åt sin dotter.

I en konstellation som denna spelar berättarrösten och berättarperspektivet en avgörande roll för en ny förståelse av texten. Crew påpekar att berättarröst och -synvinkel i just denna typ av berättelser är av stor betydelse (13-14). Vem berättar, vems perspektiv dominerar, vems röst hörs inte och framförallt; vem har potential att skrida till handling och utöva makt, är centrala frågor i mor-dotterberättelser 
eftersom tendensen enligt Crew är att döttrars röster i ungdomsromaner privilegieras enligt en freudiansk diskurs som anklagar och förnekar modern. De undantag som ändå finns ger däremot utrymme åt modern att berätta sin sida av berättelsen, hävdar Crew. Jag vill lyfta fram Reuterswärds trilogi som ett sådant undantag.

\section{Den sörjande och längtande modern}

I Du har ju pappa, Elisabet och Ta steget, Elisabet är berättaren allvetande och introspektiv, vilket innebär att berättaren följer Elisabet, Becka och Anders, går in i deras medvetande och visar händelserna genom deras ögon. I huvudsak är det genom Elisabets perspektiv som händelserna skildras och att protagonisten bara är sex år gammal i den första boken tydliggörs av de korta meningarna och en barnhärmande ton, som i det inledande kapitlet där en vanlig kväll hos familjen Hof framställs ur barnets perspektiv.

\footnotetext{
Ibland står Elisabet i dörröppningen och tittar på mamma. Mamma ser henne inte. Hon sitter med ryggen åt. Och skulle hon vända sig om, säger Elisabet fort:

- Jag ska bara gå och kissa.

[...] Elisabets mamma pluggar. Nästan alla kvällar. På dagarna är hon på Byrån, och där tar hon emot folk och lyssnar på deras bekymmer. Hon är alldeles slut, då hon kommer hem. Men läxböckerna kommer fram i alla fall. Hon får inte skolka. Det får man inte om man ska bli lärarinna. Och det ska Elisabets mamma. (Reuterswärd, Du har ju pappa 5-6)
}

Elisabet stillar sin längtan efter mamman genom att stå vid sidan av och iaktta henne. Men hon aktar sig för att göra väsen av sig eftersom hon förstår att mamman är koncentrerad på något viktigt och inte får störas. Därför har Elisabet en ursäkt färdig till hands i fall mamman skulle upptäcka henne. I den korta resumén av varför mamman läser nästan varje kväll blandas barnets syn på saken och förklaringar som en vuxen, troligtvis mamman eller pappan gett åt sin dotter för att få henne att förstå varför mamman har så lite tid för sin familj.

Trots att Elisabets perspektiv på händelserna dominerar fokaliserar berättaren även Becka vilket gör att läsaren får ny information om henne. När fokaliseringen skiftar på detta vis mellan karaktärer blir läsaren varse om hur vitt skilda uppfattningar karaktärerna kan ha om samma händelser eller omständigheter. Det här blir särskilt tydligt då ett barn och en vuxen reflekterar över samma sak. 
I det inledande kapitlet har föräldrarna fattat beslutet att Anders och Elisabet tillfälligt ska flytta ut till familjens sommarviste på Gruvö för att ge mamman läsro så att hon kan slutföra sina studier. När Anders och Elisabet gått ombord på färjan sker ett skifte i fokaliseringen, från Elisabet till Becka. Elisabet och Anders går ut på däck för att vinka åt Becka men till Elisabets stora besvikelse syns mamman inte längre till. Textavsnittet som följer är indraget för att markera växlingen $i$ fokaliseringen och inleds med orden.

\begin{abstract}
Elisabet vet inte att Becka inte kunnat stå kvar på kajen. Hon vet inte att Becka varit uppe och gått fram och tillbaka flera timmar mitt i natten inne i den nästan tomma ateljén. Hon har ingen aning om att hennes mamma då och då gått fram till bädden där Elisabet sover och stått lutad över henne tyst och sluten, med ögonen vidöppna, nakna, orörliga [...]. Becka kan inte gråta. Jo, det kan hon. Men hon gråter inte ofta. Elisabet har till exempel inte sett sin mamma gråta ... Därför vet hon inte att Becka gråter på riktigt, då hon springer bort från Blasieholmskajen in mot Grefgränd. (26-27)
\end{abstract}

Här uppstår en diskrepans mellan Elisabets besvikelse och Beckas sorg över att tvingas ta farväl av sitt barn. Av mammans förtvivlan som rymmer allt från skuldkänslor över att vara en dålig mamma, till djup och innerlig moderskärlek, vet Elisabet inget om. Genom att fokalisera Becka blottlägger berättaren viktig information som mjukar upp bilden av henne och gör att man som läsare börjar ifrågasätta det första, om man så vill; osympatiska, intrycket.

Det finns exempel som ytterligare fördjupar bilden av mamman. När Anders och Elisabet bott en tid på Gruvö, kommer Becka överraskande på besök. Under besöket låter hon Elisabet komma nära, känslomässigt och fysiskt. Att hon saknat sin käraste lika mycket som de saknat henne är uppenbart: "Jag hade simmat, om ingen båt hade gått" (64), säger Becka som en kommentar till den tjocka dimman som nästan grusade hennes planer.

På Gruvö finns också ett viktigt nätverk av vänner: "Becka känner alla och talar liksom lite olika med varenda en. Som om just dom två hade ett eget språk" (67). Den röst Elisabet gillar bäst är Beckas Oskis-röst. Oskis är Beckas barndomsvän: "Oskis-rösten är glad och munter, den är låg och förtrolig, den är varm och solig" (69). Utgående från dessa exempel är det svårt att tolka Becka Hof som den "onda" modern utan egen röst.

I trilogins andra del Ta steget, Elisabet, är tonen mörkare, dels på grund av Beckas annalkande självmordsförsök, dels på grund av 
efterspelet som följer på den tragiska händelsen. Den allvetande berättaren finns kvar men via det extensiva bruket av dialoger mellan i huvudsak Elisabet och övriga karaktärer kan man skönja avvisande attityder som riktas mot Becka Hof. I det här sammanhanget har dialogerna stor betydelse för tolkningen av mamman eftersom en stor del av dem förs om henne utan hennes närvaro.

Edström konstaterar i sin artikel att modern i Reuterswärds ungdomsromaner ofta får en nästan lika stor roll som protagonisten (201). Det stämmer att händelserna i Ta, steget Elisabet till största delen kretsar kring mammans ensamhet, självmordsförsöket och konvalescenstiden. Reuterswärd ägnar exempelvis ett helt kapitel åt att beskriva Beckas ensamhet, ur dennas perspektiv. Men det går också att skönja en tydlig utveckling i mor-dotterrelationen där dottern från att ha varit allierad med fadern lyckas bryta mammans tystnad och bygga upp en helt ny relation med denna där de två, för att parafrasera Irigaray, talar med varandra kvinna-till-kvinna och skapar en egen gemenskap.

\section{Le parler femme - den moderliga diskursen}

I essän "And the One Doesn't Stir without the Other" beskriver Irigaray den långa vägen fram till en dylik gemenskap (60-67). Utgångspunkten är en paralyserande symbiotisk enhet mellan en mor och en dotter, ur dotterns perspektiv. Dottern spelar ett dubbelspel som å ena sidan går ut på att hon måste slita sig loss från en relation med en person av samma kön (modern) för att fly det sociala tabut av en homoerotisk relation och inordna sig i den symboliska ordningen (språket, Faderns Lag). Å andra sidan måste dottern, paradoxalt nog, hålla fast vid relationen med modern för att lära sig hur man blir en kvinna.

Enligt Irigaray kan modern ändå inte vara en tillförlitlig vägledare till kvinnlighet eftersom hon förlorat sitt jag som begärande part. I detta dödläge har dottern bara ett alternativ, att frigöra sig från relationen till modern. Först som vuxen kan dottern positionera sig på nytt i relation till modern som ett likvärdigt subjekt och genom att byta ut det symboliska språket mot ett annat, ett kvinnornas språk.

Irigaray kopplar starkt ihop detta alternativa språk med det biologiska könet och exkluderar således män från den feminina diskursen. Det här är något som kan ifrågasättas, exempelvis med hänvisning till Judith Butler som i stället för att se de biologiska könen som varandras motpoler förespråkar gränsöverskridande identifikationer av begreppen "kvinna" och "man" (Butler 10-13). Enligt Butler 
är människans kön och sexualitet skapade av språket och lika kulturellt konstruerade som genus. I Elisabet-trilogins avslutande del Livet rymmer allt, Elisabet, finns den dramatiska vändningen gällande Elisabets pappa som ger belägg för Butlers resonemang. Detta återkommer jag till.

Den moderliga diskursen är central i Irigarays omarbetning av psykoanalysen: "mother/daughter, daughter/mother relationship [...] is a highly explosive nucleus. Thinking it, and changing it, is equivalent to shaking the foundations of the patriarchal order" (Iriagaray, Reader 50). Vad hon menar är att det finns en obrukad kraft i det dubbla kvinnliga, det vill säga mor och dotter, som har potential att rubba fundamenten i ett av män konstruerat och styrt samhälle.

Irigaray kallar den moderliga diskursen, genom vilken mor och dotter kan kommunicera med varandra på lika villkor, för le parler femme (This Sex 22-23). Det är en psykisk plats som ligger bortom det fallocentriska Logos, en språklig struktur som Lacan betecknar som gemensam för alla individer. I Irigarays le parler femme kan kvinnan uttrycka sig både intellektuellt och emotionellt. Platsen är inte en spegelbild av den patriarkala diskursen och logiken utan en ny variant av språket.

För att pröva Irigarays tes om den moderliga diskursen, analyserar jag i det följande dialoger och tonläge mellan karaktärer. Det som enligt mig förbisetts är att Becka Hofs självmordsförsök i förlängningen leder till en helt ny relation mellan mor och dotter, en relation i vilken Elisabet åtminstone tillfälligt kommer mamman nära, i enlighet med Irigarays tes om ett kvinnligt vi.

Kommunikationen mellan Anders och Becka har krympt till ett minimum och Anders är bitter över att hans karriär som konstnär kört fast. Enligt honom förvärrades äktenskapsproblemen då familjen flyttade till Gruvö.

- Sen blev allt precis efter det mönstret som hon hade bestämt, säjer han långsamt. Hon fick lärartjänsten. Precis som hon ville. Allt blev som hon ville. Till och med Jeppe ... blev som hon ville. Till och med Jeppe. (Reuterswärd, Ta steget, Elisabet 27-28)

Ur Anders synvinkel har Becka ordnat familjens liv utan att ta hänsyn till vad han velat. Sonen Jeppes ankomst ser han som en del av Beckas plan, vilket tyder på att han känner sig djupt besviken. När Elisabet försynt undrar när han senast ställde ut ilsknar han till: "Jag är död, Eli - stendöd som konstnär. Där har du det ... En halvdan 
snickare ... som klantar på andras områden ... inte ett jävla dugg mer ... DÖD!" (27). Redan i följande kapitel delges läsaren ändå Becka Hofs syn på varför livet blev som det blev. Bilden som ges av henne står i bjärt kontrast mot den själviska hustru- och modersbild som Anders målat fram. Hon är mycket mån om sin familj och oroar sig för familjemedlemmarna när de är ute på havet men omsorgen och de starka känslorna når aldrig fram till dem de berör.

Hon har stått i fönstret mot vägen och lyssnat efter mopeden. Hon har lagt in ved i spisen och tänt på. Snabbt har hon ställt fram dryck och bröd för dom båda. När hon ser den bleka strimman av ljus som letar sej uppför backen vet hon att dom är i säkerhet båda. (31-32)

Becka både uppmuntrar den starka relationen mellan far och dotter och känner avundsjuka för att hon står utanför gemenskapen. Därför drar hon sig hellre tillbaka och tyr sig till sonen Jeppe. "Jesper Hof är den enda människa som lyckats smälta den hinna av kyla som är Beckas signum. Han är hennes näring. Hennes bränsle" (37).

Westins psykoanalytiska tolkning av "modermordet" som en nödvändig lösning för dotterns frigörelse grundar sig på det häftiga gräl mellan Elisabet och Becka som föregår självmordsförsöket (Westin 38). I Elisabets utspel blottläggs alla uppdämda känslor som en långvarig brist på kommunikation lett till.

Du inbillar dej att du kan allting, du är så duktig och alla ska vara som du vill, men ... du kommer att åka på världens nit ... vet du det ... för ingen bryr sej egentligen om vad du säjer ... det är bara för att vi ska få vara ifred ... men det fattar inte du, för du ser inte oss ... bara ... bara dej själv ... och Jeppe. (36)

Dotterns hätska anklagelser får luften att gå ur Becka. Elisabets ord berör henne hårt men hon kan bara svara på sitt välbekanta sätt, genom att tiga. Westin ser grälet, där dottern är den anklagande parten, som orsaken till att Becka i påföljande kapitel hittas medvetslös, flytande med huvudet neråt i vattnet. Det kan delvis ses som en legitim tolkning, särskilt med tanke på att Becka några timmar senare cyklar i väg ner till stranden med avsikt att aldrig återvända. Men självmordsförsöket är inget plötsligt påfund utan något som Becka i sin förtvivlan länge funderat på.

Bevis på detta är det avskedsbrev hon lämnat efter sig. I brevet skriver Becka upprepade gånger hur mycket hon älskar sin familj men att hon är trött på sig själv och den roll hon skapat en gång, det 
vill säga rollen av den duktiga och företagsamma kvinnan. Hon ber också sin man och sina barn att inte anklaga sig själva: "Jag älskar er, och ni måste nu veta att det jag gör då jag vandrar ut till havet är en gammal dröm, den har jag alltid haft, jag måste få göra verklighet av den" (74).

\section{Mödrars roller debatteras}

Anmärkningsvärt i brevet är den hänvisning till rollen Becka Hof skapat åt sig själv. Reuterswärds trilogi är skriven under en period då könsrollsdebatten pågått sedan länge och då kvinnors inträde $i$ arbetslivet diskuterades och uppmuntrades. Toijer-Nilsson följer i sin bok upp hur dessa diskussioner avspeglas i barn- och ungdomslitteraturen och noterar att man kan urskilja olika skiftningar bland de böcker som skildrar mödrar som redan befinner sig i arbetslivet. En av dessa skiftningar gäller kombinationen yrke och moderskap som inte automatiskt gör kvinnan mogen och säker. Tvärtom åskådliggörs i flera böcker svårigheten att rent praktiskt förena föräldraskap med yrkesliv (Toijer-Nilsson 226-236).

Sara Kärrholm analyserar i en artikel 1970-talets familjevärderingar utgående från Kerstin Thorvalls bilderböcker och jämför böckernas modersporträtt med verkliga mödrar som presenteras i tidningen Vi Föräldrar från samma tidsperiod (Kärrholm 178-191). Thorvall efterlyste redan i mitten av 1960-talet verklighetstrogna fiktiva mammor i den uppmärksammade debattartikeln " Bor alla barnboksförfattare i Tomtebolandet?" Några år senare gav hon svar på sitt eget tal i form av ungdomsböcker som porträtterade trötta och stressade mammor, långt ifrån de goda sagomammor hon fördömt i sin artikel.

I tidningen $V i$ Föräldrar är mammors inträde i yrkeslivet ett återkommande tema och Kärrholm noterar en stor oro över konsekvenserna av att många mammor uppmanades att återgå till yrkeslivet och "förverkliga sig själva" utanför familjen. Oron gällde delvis barnen: skulle de fara illa på daghemmen om mammorna gav sig ut i samhället? Det fanns också en oro för mammorna: skulle de bli olyckliga i sina nya värv?

En mamma som Kärrholm citerar klär på ett beskrivande sätt i ord den problematik jag skönjer i Reuterswärds modersporträtt: "för kvinnan kvarstår en komplikation: hon kan visserligen ha lyckats ikläda sig sin nya roll ute i sitt arbete, men som mor släpar hon ännu på de gamla förväntningarna: om det mytiska i modersrollen, om att självklart vara den som betyder mest för barnet" (Kärrholm 189). 
Mot detta citat är det intressant att undersöka Becka Hofs rollskapande och det sätt hon driver sig själv till avgrundens brant. I praktiken är det hon som försörjer familjen och det är ekonomiska skäl som tvingar henne att studera i snabb takt. Hon lever under hård press och har svårt att finna en balans mellan arbete och familjeliv.

Min tolkning är att Reuterswärd med sin gestaltning av Becka Hof vill säga något om den debatt som då fördes om jämlikhet och könsroller. Om det inte var lätt för män att anamma en ny roll, som sociologen Rita Liljeström visar i sin bok Uppväxtvillkor (1973), så var det, som Reuterswärd antyder, också svårt för kvinnorna att finna en jämvikt mellan yrkesarbete och mödrarollen.

Avgörande för relationen mellan mor och dotter blir Becka Hofs "uppvaknande" på ett vårdhem. I flera månader efter självmordsförsöket har hon avskärmat sig från verkligheten genom att inte vilja tala. När Elisabet besöker sin mamma för andra gången har hon Jeppe med sig, i hopp om att han ska bryta tystnaden.

Hon sluter Beckas armar kring Jesper och själv omsluter hon dem båda i en omfamning. Hon lutar sitt huvud mot Beckas hår som är svalt och doftar citron och sjukhusrent. Med sina läppar mot Beckas hjässa känner hon hur Becka böjer sitt huvud ner mot Jespers. Eli känner hur Becka makar sin kropp lägligare för att ta emot Jeppes. Det är som en lång mjuk bågrörelse. Den börjar nånstans långt inne i Elis kropp, förplantar sej över till Beckas och tonar ut i Jespers. Nu tänker Elisabet - nu lär jag mig älska. (83)

Denna nästintill poetiskt beskrivna scen är central med tanke på mammans tillfrisknande och för läkningen av den infekterade mor-dotterrelationen. Ord är överflödiga i denna scen, det är med sin kroppsliga närhet som Elisabet får mamman att vakna upp ur sin dvala. Några veckor senare, när Becka och Elisabet åker på en kort semester till ett pensionat kommer Becka ihåg stunden i Elisabets famn: "Och själv minns Becka hur Elisabets fasta hand strök bort hennes hår. Hennes muskler minns hur armar sluts om hennes armar, hur värmen från Elisabets kropp flyter över i hennes egen. Det är i Elisabet hon minns att hon vaknar" (129).

Sonen Jeppe nämns inte i detta sammanhang utan det är uttryckligen dotterns styrka som Becka minns. Ur ett psykoanalytiskt perspektiv kan man se Becka och Elisabet återförenas i en helt ny relation, i ett kvinnligt vi där det inte finns plats för det maskulina.

I trilogins avslutande del Livet rymmer allt, Elisabet flyttar Elisabet, som nu fyllt 20 år, hemifrån. Det inledande kapitlets titel, "Nu är det 
min tur", vittnar om att Elisabet ser fram emot frigörelseprocessen från föräldrarna men antyder också att mycket av familjelivet hittills i hög grad kretsat kring föräldrarnas problem.

Elisabets flytt och det stagnerade parförhållandet gör att föräldrarna står inför en situation som väcker oro hos dem båda. De är inte oroliga för Elisabet utan för det nya de själva ställs inför: "Vi gillar att du reser, men vi är väl lite undrande hur vi ska klara av att vara ensamma. Du vet hur vi är. Sol och måne, men sällan på samma gång" (Reuterswärd, Livet rymmer 12). Så förklarar Anders sin ängslan för Elisabet och antyder samtidigt att Elisabet fyllt en viktig funktion i familjen, den som buffert mellan föräldrarna.

Trots att fokus i Livet rymmer allt, Elisabet inte längre är på föräldrarnas interna angelägenheter hörs mammans röst via ett brev till Elisabet. I brevet beskriver Becka hur hon lärt sig acceptera den frigörelse som nödvändigt måste ske mellan en mor och ett barn.

Vad jag vill säga till dej egentligen är att din frihet är nära kopplad till min egen. Just nu tror jag att du har större möjligheter, har större resurser än jag att förvalta den friheten. Men att jag, även jag alltså och naturligtvis pappa, måste lära oss att nyttja den och göra den till något spännande, något värt att erövra, för egen del. (76-77)

Becka verkar stå på randen till ett svårt beslut där hon måste välja mellan att stanna kvar i ett dåligt förhållande eller frigöra sig från det. Beslutet är inte fattat men insikten om att en förändring är möjlig finns där.

Brevet visar enligt mig på mammans förtrolighet med den nu vuxna dottern där hon liknar dotterns frigörelse vid sin egen. Beckas öppenhet, både emotionellt och intellektuellt påminner om den plats Irigaray omtalar som den moderliga diskursen där mor och dotter återförenas och talar ett språk som ligger bortom det patriarkala (This Sex 22-23). Beckas förtrolighet antyder att hon kommunicerar med Elisabet på lika villkor och behandlar sin dotter som den vuxna kvinna hon nu är.

Beckas frigörelse blir än mer tydlig i trilogins avslutande kapitel. Elisabets vistelse i Malmö slutar dramatiskt och hon flyr hem till Stockholm. Där inser hon att föräldrarna är på väg ifrån varandra.

Pappa tänker hon ropa. I samma ögonblick slår det henne att han kanske hört dörren slå, och stegen genom hallen. Men han vänder inte på huvudet. Han öppnar inte munnen för att säja: "Hej, tjena, chiao ..." Han fortsätter helt enkelt att teckna. Som om ingen hade kommit in i huset. (99-100) 
Äktenskapet har gått in i en fas där Becka och Anders bor under samma tak men inte längre delar vardagen. Trots att Elisabet vetat om svårigheterna är pappans reaktion, eller icke-reaktion, upprörande och Elisabet känner smärta å mammans vägnar. Senare får hon höra att Anders i tiderna varit olyckligt förälskad i en annan man, en hemlighet han burit inom sig under alla år som gift man. När Elisabet frågar om mamman vet, lyder Anders kommentar: "Med mamma talar man mycket lite om sånt här ..." (116).

För läsaren har det vid flera tillfällen framgått att Anders har lättare för att prata med Elisabet. Att han inte haft förtroende att delge sin hustru hemligheten säger mycket om relationen mellan dem. Han är ändå redo att berätta om sitt forna liv för Elisabet och jag tolkar det som att även han gör sig fri från det förgångna och förbereder sig för att vända blad.

Här kan man, för att återknyta till Butlers resonemang om gränsöverskridande identifikationer, hävda att Anders med sin ambivalenta sexualitet och förmåga att kommunicera med sin dotter, inte är bunden av en patriarkal diskurs. Detta underbygger i sin tur tolkningen att Irigarays le parler femme även kan vara en plats som individer av olika biologiska kön kan identifiera sig med.

Vid denna bekännelse avslutar Reuterswärd sin trilogi, i ett skede då de centrala karaktärerna på olika sätt nått en vändpunkt i livet. Hur förändringen ser ut för dem förblir osagt men antydan är att de alla tre är på väg mot något nytt.

\section{Slutsats}

Reuterswärds trilogi är exceptionell såtillvida att den i hög grad handlar om protagonistens mamma. Även den avslutande delen, $\mathrm{Li}$ vet rymmer allt, Elisabet, skildrar inte bara Elisabets mognadsprocess utan även mammans. Becka Hofs inre värld tydliggörs via skiften i fokaliseringen och via brev. Den modersbild som framträder överensstämmer ofta dåligt med den bild som kommer fram via andra karaktärers funderingar kring och dialoger om mamman. Jag menar att moderskaraktären varken är statisk eller stereotyp utan psykologiskt komplex och försedd med en egen röst som utvecklas mot slutet. Genom att ta sig ur sin depression och inte vilja låsa sig fast $\mathrm{i}$ en viss roll sticker Becka Hof ut från liknande dysfunktionella, depressiva eller emotionellt frånvarande moderskaraktärer i 1970-talets samtidsrealistiska ungdomsromaner.

Den mamma som Reuterswärd beskriver är inte "monstruöst elak" eller förlorad i sin egen narcissism utan en mamma som vill 
skapa en egen stark yrkesidentitet och samtidigt vara en bra mamma åt sina barn, en kombination som visar sig vara svår att förverkliga. Vidare leder svårigheterna i att öppna sitt inre för sin familj till friktioner i relationerna till dels Elisabet, dels Anders. Genom att ändå ge röst åt mamman visar Reuterswärd solidaritet med och medkänsla för inte bara den fiktiva mamman utan för alla 70-talsmammor som befann sig i liknande positioner, uppmuntrade till yrkesarbete samtidigt som de förväntades vara lika närvarande för sina barn som tidigare kvinnogenerationer.

Becka Hof är en kvinna som i kvinnofrigörelsens spår vill bemästra livets alla områden, som mamma och som yrkesarbetande kvinna. Men trycket blir för stort och leder till en svår depression. Hon lyckas ta sig upp ur avgrundsdjupet tack vare sin dotter. Den till en början ordlösa kommunikationen mellan mor och dotter leder så småningom till Beckas tillfrisknande och en helt ny och hel relation mellan dem.

Toijer-Nilsson lyfter i sin resumé av Elisabet-trilogin fram en viktig aspekt, nämligen den att författaren inte bara ifrågasätter gamla rollmönster utan även blottlägger människors psyken (107). Det är ett humant modersporträtt som Reuterswärd tecknar, och samtidigt visar hon hur lite vi egentligen vet om varandra, också om våra närmaste, och hur livet kan ta vändningar vi sällan har möjlighet att förutse. Men framför allt visar hon att frigörelsen, detta ungdomsromanens återkommande temata, i lika hög grad kan gälla vuxna samt att en smärtfri och på lika villkor pågående relation mellan barnet och föräldern i ett irigarayskt le parler femme inte är bunden av deras kön.

Biografisk information: Pia Vuorio är doktorand i litteraturvetenskap vid Åbo Akademi i Finland. Hennes doktorsavhandling behandlar moders- och fadersfigurer $i$ svensk samtida ungdomslitteratur publicerad mellan 1968 och 1980 ur ett psykoanalytiskt perspektiv.

\section{Litteratur:}

Butler, Judith. Genustrubbel. Feminism och identitetens subversion. Övers. Suzanne Almqvist. Göteborg: Bokförlaget Daidalos, 2007.

Crew, Hilary S. Is it really 'Mommie dearest'? Daughter-Mother Narratives in Young Adult Fiction. Lanham, Maryland \& London: The Scarecrow Press, Inc., 2000. 
Edström, Vivi. "Fångenskapssymboler i ungdomsboken". Läs mig sluka mig. En bok om barnböcker. Red. Kristin Hallberg. Stockholm: Natur och Kultur, 1998. 181-210.

Franck, Mia. "Öronbedövande tystnad. Flickskildringen i Peter Pohls Anette-böcker". Barnlitteraturanalyser. Red. Maria Andersson \& Elina Druker. Lund: Studentlitteratur, 2008. 149-161.

Grosz, Elizabeth. Sexual Subversions. Three French Feminists. New South Wales: Allen \& Unwin, 1989.

Irigaray, Luce. "Etablir un généalogie des femmes". Maintenant. 1979:12. 119-121.

Irigaray, Luce. "And the One Doesn't Stir without the Other". Signs. 1981(7):1. 60-67.

Irigaray, Luce. The Irigaray Reader. Red. Margaret Whitford. Blackwell Cambridge Mass., 1991.

Irigaray, Luce. This Sex Which is Not One. Övers. Catherine Porter \& Carolyn Burke. Ithaca: Cornell University Press, 1985.

Jönsson, Maria. Behovet av närhet blir med åren betydligt större än nödvändigheten att bevara sin värdighet. Om genus, trots och åldrande $i$ Kerstin Thorvalls författarskap. Lund: ellerströms förlag, 2015.

Kärrholm, Sara. "Trötta mammors försvarare. Familjevärderingar i Kerstin Thorvalls bilderböcker från 1970-talet". Barnboken. 2011:2. 178-191.

Larsson, Lisbeth. "På jakt efter den moder som försvann". Nordisk kvinnolitteraturhistoria, band IV. På jorden 1960-1990. Höganäs: Bra Böcker, 1997. 255-265.

Liljeström, Rita. Uppväxtvillkor. Samspelet mellan vuxna och barn i ett föränderligt samhälle. Stockholm: Publica, 1973.

Moberg, Eva. "Kvinnans villkorliga frigivning". Unga liberaler. Nio inlägg i idédebatten. Red. Hans Hederberg. Stockholm: Albert Bonniers förlag, 1961. 68-86.

Reuterswärd, Maud. Du har ju pappa, Elisabet. Stockholm: Albert Bonniers Bonniers, 1971.

Reuterswärd, Maud. Ta steget, Elisabet. Stockholm: Albert Bonniers Förlag, 1973.

Reuterswärd, Maud. Livet rymmer allt, Elisabet. Stockholm: Albert Bonniers Förlag, 1975. 
Rich, Adrienne. Av kvinna född. Moderskapet som erfarenhet och institution. Övers. Hilja-Katarina Wallin, Stockholm: Rabén \& Sjögren, 1980.

Svensson, Sonja. "Ett släkte för sig. Om åldersbarriärer i den svenska ungdomboken 1950-1975". Kring den svenska ungdomsboken: analys, debatt, handledning. Red. Ulla Lundqvist \& Sonja Svensson. Stockholm: Natur och Kultur, 1977. 11-63.

Thorvall, Kerstin Thorvall. "Vart ska du gå?" Vet inte". Stockholm: Albert Bonniers Förlag, 1975.

Thorvall, Kerstin. "Bor alla barnboksförfattare i Tomtebolandet?" Expressen. 26 sept 1965.

Toijer-Nilsson, Ying. Berättelser för fria barn. Könsroller $i$ barnboken. Skrifter utgivna av Svenska Barnboksinstitutet 10. Göteborg: Stegelands, 1978.

Trites, Seelinger, Roberta. Waking Sleeping Beauty. Feminist Voices in Children's Literature. Iowa City: University of Iowa Press, 1997.

Westin, Boel Westin. "Mammor och omödrar. Modersbilder i barnoch ungdomslitteraturen. Opsis Kalopsis. 1996:2. 37-39.

Wilkie-Stibbs, Christine. The Feminine Subject in Children's Literature. New York \& London: Routledge, 2002. 